\title{
Medicine and Books
}

\section{Freud and the "White Hotel"}

\author{
D M THOMAS
}

I suppose that since Freud in my book talked about the original white hotel as the place where everyone has stayed I could say that I started to write the IY'hite Hotel in the womb, and I think the book does have all of my life experience there in some form or other. But I really began to write it about six years ago. I was reading the letters of Jung and Freud, both of them fascinating people, and was particularly struck by the moment when their relationship, already under strain, broke off. There was a famous occasion in May 1912 when Freud travelled from Vienna to Lake Constance one weekend to visit a sick colleague, Binswanger, who had cancer; Jung, of course, was living just near Constance at Zürich and he thought that as Freud had come such a long way it would not be far to come the extra few miles to see him for a few hours at Zürich-while Freud thought that, as he was going all that way and he was much the older man, surely Jung could take the train journey on the branch line into Constance to see him for a few hours at Binswanger's clinic. As a result neither of them met, and it seemed to me, perhaps in my ignorance, a classic illustration of the tug between father and son: Jung was a sort of spiritual son of Freud and that marked symbolically the end of the relationship. I wrote a poem about it.

\section{Vienna, Zürich, Constance}

It was a profound unmeeting.

The train on the branchline from Zürich to Constance

Held a carriage which held a compartment

With a white seat-cover with an impression of Dr Jung,

Slit eyes, in a pugnacious bullet head,

By no means the merry young man of his old age.

The young woman opposite, bright

In a black-and-white striped dress, a blue neck-scarf,

Did not chat to the man not touching his brief-case

But read through the short journey, smiling occasionally,

Nor did she follow him out at Constance,

Where he was warmly embraced by an older man.

The train on the branchline from Constance to Zürich Held a carriage which held a compartment

With a white seat-cover with an impression of Dr Freud,

His face graven with battles, genial-eyed.

The young man opposite in a modern, very

Tight brown suit with a heavy Victorian watch-chain

\section{Hereford HR4 OBE}

D M THOMAS, author, poet, and translator

A transcript, minimally revised by the author, of an informal lecture he gave at the Albert Einstein College of Medicine (Department of Psychiatry), New York, in January 1982.
Was not startled by the old gent not leaning forward

And not telling him with a twinkle why he had stammered

Momentarily over the word Constance,

But rubbed his hands dreamily and gazed out.

Nor did he help him with his case at Zürich

Where he was greeted cordially by his son.

By a strange coincidence

The young woman who would have been in Jung's compartment Had Jung been travelling, was the mistress

Of the young man who would have been in Freud's compartment

Had Freud been travelling.

Having confused

Their plans, they passed each other, unaware.

Waiting for him in her hotel at Constance,

The young woman stepped out of her rainy clothes.

Her fur hat momentarily became a vulva.

Waiting for her in his hotel at Zürich,

The young man stared irritably out of the window

And saw an uncanny light pass across the sky.

Emma and the children leaving the table,

The sage head darkly reflected in its polish

Did not gracefully accept the modified libido theory.

Gazing into the waters of Lake Constance,

A fatherly hand resting on his shoulder,

Jung did not smilingly abjure his mystical drift.

Freud dined sombrely with the faithful Binswanger, And pleaded a headache. Jung worked late. Owls hooted.

In their uneasy sleep the two exchanged their dreams.

Snow fell on the Jungfrau. Lenin dreamlessly slept.

The centuries slowly drifted away from each other.

In Emma's kitchen-drawer a knife blade quietly snapped.

(The irony of the whole thing was that Jung afterwards realised that he had not been home at all that weekend; he had been away, so that he could not have seen Freud anyway. So Jung built this whole quarrel out of a non-event, completely forgetting that he had not been at home and so could not have got Freud's letter, which was sent a little late. It was a very Freudian slip of the memory.)

In that poem, looking back, I can see themes that came out later in the White Hotel. There is the theme of the paranormal knife blade snapping; this was the knife which did snap in Emma Jung's kitchen drawer. Jung and Freud were talking, with Jung arguing for the paranormal and telepathy and so on, and there was this bang in the cabinet; Freud jumped angrily in surprise and Jung said, "There you are, you see, and it will happen again just to prove it." And then there was another bang. We are told that Freud did not quite trust Jung after that.

\section{"The woman to Sigmund Freud"}

But the main thing that started off something in my mind was the idea of a journey to a hotel and these figures; figures of a young woman in a black and white striped dress and a young 
man, who represented Jung and Freud respectively. I think I chose a woman for Jung because of the anima and I saw Freud at that time as representing an older tradition-a kind of nineteenth century tradition.

The young woman on the train haunted me in particular. I did not know what to do with her, and then sometime later in Ernest Jones's biography of Freud I was intrigued to read a sentence or two about how Freud was analysing a patient and she told him that she was having an affair with one of his sonsI forget which one, but I thought how extraordinary that Freud should analyse this patient and go into her sexual life in great detail, and inevitably get secrets of his own son from it. I thought, maybe some day I will write something about that.

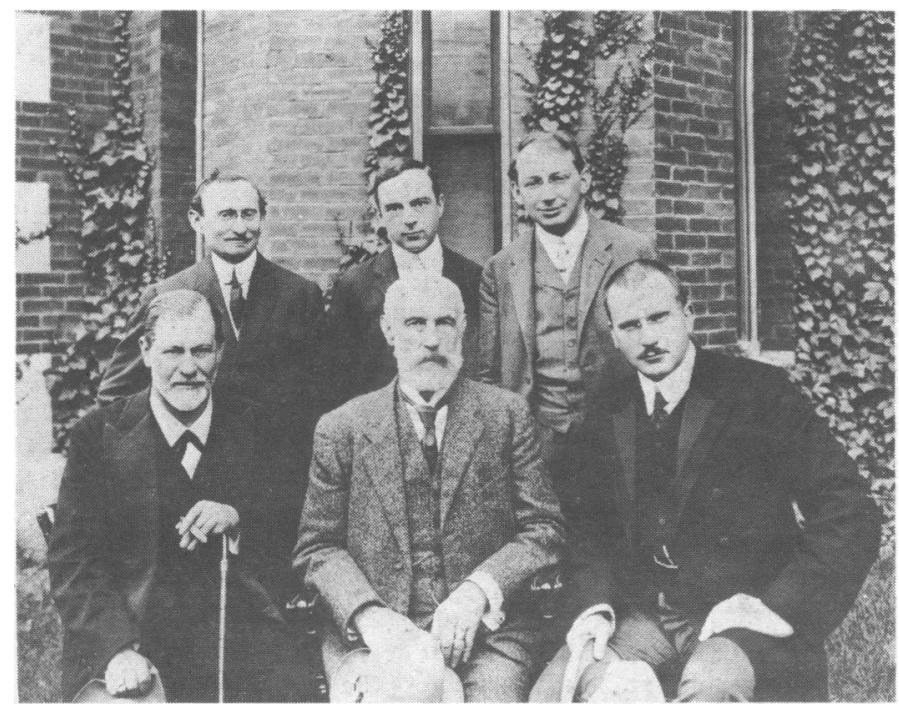

Freud, Jung, and Ferenczi at Clark University, Massachusetts, in 1909. Left to right, back row: A A Brill, E Jones, $S$ Ferenczi; front row: $S$ Freud, $S$ Hall, C G Jung. (Mary Evans/Sigmund Freud Copyrights.)

And in fact four years ago there came a burst of poetry about this woman and her affair with Freud's son, which I called just "The woman to Sigmund Freud." I knew nothing about her and it was very much an unconscious burst of images; it was the beginning of the section of the poem I later called Don Giovanni, which opens the White Hotel.

At the time I did not understand all this poem or feel that it was finished. I thought that perhaps it needed to be a part of a bigger whole so I thought I would write three more poems and see where they took me. Of course, Eros is mixed up with Thanatos-sexual fantasy mixed up with disasters - and in this first part of the poem there are drownings on a lake in a storm and in the second one a fire in the hotel. In the third section there is an avalanche and in the fourth an accident with the ski lifts. I think it really all began with these poems. In fact, the first poem was printed separately in a science fiction magazine, though it still did not seem finished and I put it aside.

\section{Babi Yar}

The key moment was reading Anatoli Kuznetsov's Babi Yar, which I bought only because it was a fat book and I was going on a long journey. When I read the eye witness account that he quotes of Babi Yar by one of the few people who escaped I was very moved; Babi Yar had just been a name to me previously. But this was such a wonderfully moving account and suddenly I saw a connection-not a logical one but a metaphorical connection-between Babi Yar and the poems that I had written. It suddenly occurred to me that the people who were the early analysts, and who were analysed, were largely Jews. So to some extent one could argue that the analysis created by Freud was a kind of opposition dogma to the religion which he had rejected -a new faith.

Then, of course, I thought of Freud's book Beyond the Pleasure Principle, where he talks about the balance of Eros and Thanatos, which I reread and found a beautiful book. It seems to be undeniable that there was this urge towards pleasure in all of us but also some self destructive instincts like the child building the tower of bricks and then pulling it down again and leaving it there. Here in 1940 in the holocaust surely was man's greatest act of self destruction. Again, Freud was trying, in his view, to cut out some kind of spiritual cancer in an individual, some kind of shadow which had to be exposed to the light and got rid of because it was causing pain or some kind of hysterical tension. Similarly, in their way the Nazis were trying to cut out a shadow, which they called the Jews. Of course, we know that the shadow was in themselves, but they projected it and they thought that if they killed the Jews then humanity, or at least the Germans, would be all right. So there were not exactly similarities but the kind of excitement that as a poet I get when a good metaphor comes.

I immediately knew that those poems had really been waiting a long time for a novel and that they would be, as I thought, the beginning of a novel, and it would end with Babi Yar. It occurred to me too that for a woman analysed by Freud in, say, 1919 her hysteria might just as easily be a premonition of what was going to happen as, in Freudian terms, the result of what had happened in childhood. Or at least that would be a good basis for a novel. Obviously in 1919 the Jewish final solution was already on the agenda; even before that, in 1905 in Odessa, there were documents by anti-Jewish organisations recommending the extermination of the Jews. So it did not seem unlikely that a young Jewish woman with sensitivity, surviving the first world war, perhaps married to an anti-Semite (although that idea came later), would be aware of future suffering. This seemed a good idea, so I had my two spans of the bridge of my novel. It merely remained to fill in the middle.

\section{Freud's case histories}

I thought that I had better find out who my heroine was. All I had to go on was the product of my own unconscious, after all-the poem. One of the greatest excitements of writing the book was that I knew that I would be able to write my case study along the lines of Freud's. I had loved Freud's case studies for a long time and I had wanted to write a novella-a short novel or a long short story-in the style of Freud himself. It hadn't come, but now it need not be a novella but a section in my novel.

So, out of the poem and the prose fantasies, I had to think about what kind of woman she was and where she had been born and so on. The first section of every Freudian case study that I know of is simply a background history of that person where she was born, and so on. So those four or five pages in my book were very important. When I began I did not know who she was or where she was born. I am very lazy, not like most novelists, who go in for lots of research; if I can get away with none I do so and it so happens that I had some knowledge of Anna Akhmatova, a great Russian poet whom I had translated, and I knew her life fairly well. She had been born on the Black Sea in 1890 and later went to St Petersburg and I knew these places, the fashions, and the styles of the period. So I decided to have my heroine born in Odessa in 1890 and happen to go to St Petersburg when she was about 17-so I would not have to do any reading! It seemed to work all right, and, of course, from St Petersburg she had to get to Vienna and eventually to Kiev.

Those were the simple boundaries within which I could create this character. Then I had to think what Freud would have made of that prose passage and the poem: what kind of woman, what kind of psychology? The most difficult part was 
creating this case study. I loved Freud's style, his rather dry reticent way of approaching very lurid erotic events. People are having incestuous scenes with their brothers in law or whatever, but Freud puts it so delicately and always uses not their real names but Frau Anna or Frau M, which seems to give it the mystery of a detective story.

After a while I did not find too much difficulty in hitting Freud's style, and in the end it was difficult not to write like Freud. I love the way that he brings in cultural allusions, quotations from poetry; this is the humanism of Freud that I admire so deeply. I make him say in a footnote that psychoanalysis and literature illuminate the human face from a different angle in all its nobility and sorrow. For me as a layman not knowing Freud, never having studied him, never having been analysed even, it is the humanity of Freud, in the sense of being deeply rooted in all the human cultures, that I value and that I suspect that some modern psychology ignores.

\section{From Vienna to Kiev}

The year 1919 was a terrible time, with hunger in Vienna, deep suffering, and horrible inflation, and the whole atmosphere seemed to me suggestive almost of the approach of the end of civilisation: Freud in his study, wearing gloves and mufflers and shaking with the cold. I decided to set the case study there in 1919 but then I had to get my character, Lisa Erdman, through 20 years to Kiev. The next section had to be straight narrative at a rather rapid pace and I had to find a reason for her to go to Kiev. I made her an opera singer with one big moment in her life when she goes to La Scala in Milan and is invited to sing as a replacement for the real star. She meets a Russian singer there and eventually marries him and goes back with him to Kiev. So that was the straight narrative, in which the voice is impersonal.

Then I knew that the love section would have to be very detailed, slow moving-an agonisingly slow reconstruction of the days, the first day, at Babi Yar. That was a very agonising section to write and I could do that only by concentrating on making it bearable by trying not to sensationalise what is already immeasurably sensational and terrible. I remember Janet Baker, the great singer, saying that, though in a rehearsal she might shed a tear, when it came to the night the singer could not cry although she wanted the audience to cry. That is very true of all art: it has to do with what Yeats called casting a cold eye on life, and on death.

But as I wrote that final section it occurred to me that I could not possibly leave Lisa Erdman there in that ditch and I had to bring her out. So I used the hint that Kuznetsov gave that some of the Jews did genuinely believe that they were being sent to Palestine in trains. Finally the characters end up in a kind of other worldly Palestine-though there is nothing paradisal about the suffering that is still going on there-and Freud, of course, is there with cancer of his jaw, trying to get cured of it, and Lisa's mother has had half her face burned off. It is in fact purgatory if one wants to use the theological term. Some people find that bringing Freud at all into a novel is totally objectionable, but to me Freud is a myth. Though he really existed, he belongs to history and mythology and represents something far greater than even a very gifted individual. $\mathrm{He}$ was born in the richness of bourgeois Vienna and died in that terrible exile of cancer in London in 1939, and his four sisters died in the Nazi camps. In his own lifetime he saw so much of the destruction of the culture he believed in.

\section{Ferenczi's letter}

There was then another problem: I could not expect readers to start with a poem. So I thought that I would have to announce it with a prologue. It seemed that I ought to start way back first of all and not with Freud or even with Jung, but with
Ferenczi on that remarkable journey of the analysts to America.

In the first letter of Ferenczi from America there are one or two images that came to me unexpectedly, which I thought worked in rather well.

Standish Hotel, Worcester, Massachusetts, USA 8 September 1909

\section{Dearest Gisela,}

I give you a warm bear hug from the new world! What with the journey, the hospitality, the lectures, the honours (mostly to Freud naturally and, to a lesser extent, Jung) there has hardly been time to blow one's nose and my mind is in a whirl. But it's already more than clear that America is eager to receive our movement. Brill and Hall are excellent fellows, and everyone at Clark University has overwhelmed us with kindness and compliments. Freud astonished even me with his masterly skill, by delivering five lectures without any notes-composing them during a half-hour's walk beforehand in my company. I need hardly add that he made a deep impression. Jung also gave two fine lectures, about his own work, without once mentioning Freud's name! Though on the whole the three of us have got on splendidly together, in rather trying circumstances (including, I may say, attacks of diarrhoea in New York . . . !) there has been a little tension between Jung and Freud. . .

I must tell you of the rather extraordinary occurrence in Bremen, on the eve of our departure. We were heartily thankful to have made a successful rendezvous, and naturally excited by the adventure lying ahead of us. Freud was host at a luncheon in a very luxurious hotel, and we persuaded Jung to abandon his customary abstemiousness and join us in drinking wine. Probably because he was not used to drinking he became unusually talkative and high spirited. $\mathrm{He}$ turned the conversation to some "peat bog corpses" that apparently have been found in northern Germany. They are said to be the bodies of prehistoric men, mummified by the effect of humic acid in the bog water. Apparently the men had drowned in the marshes or been buried there. Well, it was mildly interesting; or would have been had not Jung talked on and on about it. Finally Freud burst out several times: "Why are you so concerned with these corpses ?" Jung continued to be carried away by his fascination with the story, and Freud slipped off his chair in a faint.

Jung, poor fellow, was most upset by this turn of events - as was I -and couldn't understand what he'd done wrong. When he came round, Freud accused him of wanting him out of the way. Jung, of course, denied this in the strongest terms. And he is really a kind, lively companion, much more pleasant than those gold rimmed glasses and that close cropped head suggests.

Another brief disagreement occurred on the ship. We were entertaining ourselves (in the fog!) by interpreting each other's dreams. Jung was greatly taken by one of Freud's, in which his sister in law (Minna) was having to toss bundles of corn at harvest time, like a peasant, while his wife looked idly on. Jung, somewhat tactlessly, kept pressing him for further information. He made it clear that he thought the dream had to do with Freud's warmth of feeling for his wife's younger sister. I was staggered that he had so much knowledge of Freud's domestic affairs. Freud was naturally very put out, and refused to "risk his authority," as he put it, by revealing anything more personal. Jung said to me later that at that moment Freud had lost his authority, as far as he was concerned. However, I think I managed to smooth over the matter, and they are on good terms again. But for a while I felt like a referee in a wrestling contest! All very difficult. Keep this under your hat.

My own dream (the only one I could remember) was about some trivial childhood disappointment. Freud of course had absolutely no trouble in guessing that it related to you, my dear. He saw straight to the point: that I fear your decision not to divorce your husband until your daughters are married is a self-deception on your part, and that you do not wish to consummate our long relationship by such a profound tie as marriage. Well, you know my anxieties, and you have done your best to dissipate them; but I could not avoid dreaming of them, you see, during our parting (and probably affected by the depressing sea mist). Freud helped a good deal, as always. Tell Elma he was touched by her good wishes, and says he is deeply moved that she found her analysis with him so helpful. He also sends you his respects, and said good humouredly that if the mother equals the daughter in charm and intelligence (I assure him you do!) I am an enviable man ... I know that! Warmly embrace and kiss Elma from me, and pass on my respects to your husband. . . Meanwhile 
I kiss you (and heavens! much worse! much better!) in my dreams. Forever your Sandor Ferenczi.

Of course, the events are accurate and I tried to keep all the Freudian events within the known truth of his life: Freud did faint, and Jung did talk about "peat bog corpses" that had been found in northern Germany. This latter was really itself an extraordinary coincidence when one thought of the other kind of peat bog corpses which later in the century the Germans were desperately trying to dig up to try and cover their traces of Babi Yar. Other smaller things which tie in are the dream of Minna tossing bundles of corn and the image of the Nazis in the last section tossing children like bundles of corn over the wall. Now I am fascinated to find a growing possibility that Freud did have an actual affair with his sister in law.

In his case studies Freud was often fictionalising: he was very much more involved emotionally than he lets on, I think. As I reread the case studies I discovered that they were not only like Greek dramas (in that they led very slowly up to a point of revelation) but they were also intellectual acts of love. Let me just read to you a little bit from Fraulein Elizabeth von $\mathrm{R}$, the case I have relied on much more than any other as to formal construction in my version of Freud.

"It has inevitably become clear to me long since what all this was about, but the patient deep in her bitter sweet memories seemed not to notice the end to which she was steering and continued to reproduce her recollections. She went on to her visit to Gastein. The anxiety with which she looked forward to every letter, banished the bad news about her sister who was dying after a pregnancy. The long wait till the evening, which was the first moment at which they could get away from Gastein, and the journey passed in tormenting uncertainty and the sleepless nights. All of these accompanied by a violent increase in her pain. I asked her whether during the journey she had thought of the grievous possibility which was afterwards realised. She answered that she had carefully avoided the thought but she believed that her mother had from the beginning expected the worst. Her memory now went on to their arrival in Vienna. The impression made on them by the relatives who met them. The short journey from Vienna to the summer resort and its neighbourhood where her sister lived. Their reaching there in the evening. The whole walk through the garden to the door of the small garden house. The silence within and the oppressive darkness. How her brother in law was not there to receive them and how they stood before the bed and looked at her sister as she lay there dead. At that moment a dreadful certainty that her beloved sister was dead without bidding them farewell and without her having eased her last days with her care. At that very moment another thought had shot through Elizabeth's mind and now forced itself irresistibly on her once more like a flash of lightning in the dark; now he is free again and I can be his wife.

"Everything was now clear. The analyst's labours were richly rewarded. The concept of a sending off was an incompatible idea. All these things were at that moment brought before my eyes in a concrete form and the period that followed, however, was a hard one for the physician. The recovery of this repressed idea had a shattering effect on the poor girl. She cried aloud when I put the situation dryly before her with the words, "So for a long time you have been in love with your brother in law ?' She complained at this moment of a most frightful pain and made one last desperate effort to reject the explanation. It was not true, I had talked her into it, it could not be true. She was incapable of such wickedness. She could never forgive herself for it. It was easy to prove to her that what she herself had told me admitted of no other explanation. But it was a long time before my two pieces of consolation, that we are not responsible fur our feelings and that her behaviour, the fact that she had fallen ill in these circumstances, were sufficient evidence of her moral character. It was a long time before these consolations of mine made any impression on her."

What I am getting at is not only the sheer artistry of that but that this is an orgasmic moment in the story and it comes about three quarters of the way through. Here's Freud fingering away with a patient, and more, and she is resisting like mad. And then of course there is her acceptance of it, her gradual acceptance that she has been seduced, and then a kind of dying away of the affair and usually ending not on a note of triumph. Freud doesn't say that she would never have any troubles again. They part usually on good terms. It's like a story by Arthur Schnitzler set in Vienna-a love story. These are white hotel stories that Freud was writing. I am not saying that they were not clinically accurate, although I suspect that for Freud it was just as important to get a good story, a well shaped classical Greek story, as to get at the truth.

Coincidences play an important part in the book. The whole book really is a mesh of intricate images and patterns which never have to be forced. My final letter, the last bit of writing in the whole book (though it appears in the prologue), is when Freud sends the case study with Lisa's writing, the "pornographic" poem, and so on to the Secretary of the Goethe Centenary Committee because they had commissioned a work from Freud to mark the centenary of Goethe's death. Freud tries to excuse the objections that the material will meet by directing the Germans to Goethe's own attitude to such uncomfortable matters. So he says: "I hope you will not be alarmed by the obscene expressions scattered through her poor verses, nor by the somewhat less offensive, but still pornographic, material in the expansion of her phantasy. It should be borne in mind that (a) their author was suffering from a severe sexual hysteria, and (b) the compositions belong to the realm of science, where the principles of nihil humanum is universally accepted and applied; and not least by the poet who advised his readers not to fear or turn away from 'what, unknown or neglected by men, walks in the night through the labyrinth of the heart." ",

I don't know Goethe and I don't know German poetry very much at all. So I had to look up an anthology hoping to find a suitable quotation. In the Penguin Book of German Verse I found a poem "To the moon" with those lines in it and I thought, "that sounds very Freudian; Freud might have used those such words." Later I remembered that Freud had indeed been given the Goethe prize for literature in 1930 and had written an address of thanks, which was delivered by Anna Freud, his daughter, in his absence because of illness. I thought that I had better read that address just out of curiosity. I had never read it before, and there was one quote and it is exactly those lines that I have used. I did not know whether to be delighted that it showed I was on the same sort of right wavelength with Freud or displeased because if people knew their Freud very well they would say, oh he just took that out of that address. But it is an astonishing coincidence.

The poem Vienna, Zurich, Constance was reproduced from The Honeymoon Voyage by permission of Secker and Warburg and the letter from Sandor Ferenczi from The White Hotel, Victor Gollancz (1981) and Penguin Books.

[We thank Dr Evan H Bellin, Deputy Director Clinical at Bronx Psychiatric Center, for lending the $B M \mathcal{F}$ a tape recording of $\mathrm{Mr}$ Thomas's lecture for transcription.-ED, BMf.] 